\title{
Restricted Immunoglobulin VH Usage and VDJ Combinations in the Human Response to Haemophilus influenzae Type b Capsular Polysaccharide

\author{
Nucleotide Sequences of Monospecific Anti-Haemophilus Antibodies
} and Polyspecific Antibodies Cross-reacting with Self Antigens
}

\author{
Elisabeth E. Adderson, " Penelope G. Shackelford, ${ }^{\star}$ Anthony Quinn, ${ }^{*}$ Patricia M. Wilson, ${ }^{\star}$ Madeleine W. Cunningham," \\ Richard A. Insel," and William L. Carroll* \\ *Eccles Program in Human Molecular Biology and Genetics and Department of Pediatrics, University of Utah, Salt Lake City, Utah \\ 84112, ${ }^{\ddagger}$ Division of Infectious Diseases, Mallinckrodt Department of Pediatrics, Washington University School of Medicine, St. Louis, \\ Missouri 63110; $\$$ Departments of Microbiology and Immunology, University of Oklahoma, Oklahoma City, Oklahoma 73190; and \\ "Department of Pediatrics, University of Rochester School of Medicine and Dentistry, Rochester, New York 14642
}

\begin{abstract}
To examine the human antibody repertoire generated against a biologically significant antigen we have obtained sequences of heavy chain variable region genes ( IgVH) from 15 monoclonal antibodies specific for the capsular polysaccharide of Haemophilus influenzae type b (Hib PS). All VH segments are members of the VH3 family and 9 of 15 are members of the smaller VH3b subfamily. Restriction is evident by the shared use of certain VDJ joints in independent hybridomas from different subjects. Two hybridomas generated from the same subject demonstrate identical heavy chain variable region gene sequences but differ in isotype and rearrange alternative light chain variable region genes ( $\mathrm{IgVL}$ ), suggesting that in a normal immune response, a single pre-B cell clone may use different light chain rearrangements and give rise to progeny capable of reacting with antigen. Using a polymerase chain reaction assay optimized to detect base pair differences among VH genes we demonstrate that at least a portion of expressed antiHib PS VH genes have undergone somatic mutation. Anti-Hib PS heavy chain genes are homologous to VH segments encoding autoantibodies and two hybridomas secrete anti-Hib PS antibody that cross-reacts with self antigens (double-stranded DNA and single-stranded DNA). Comparison of VH regions of self-reactive and monospecific anti-Hib PS Ab demonstrates no consistent structural feature correlating with fine antigen specificity. These data demonstrate significant restriction in VH usage and VDJ recombination in the anti-Hib PS response and confirm that autoantibodies may be elicited during normal immune responses. (J. Clin. Invest. 1993.91:2734-2743.) Key words: antibody repertoire $\bullet$ autoimmunity $\bullet$ immunoglobulin heavy chain • somatic mutation • polysaccharide
\end{abstract}

\section{Introduction}

Antigen-specific immunity depends upon the production of a vast number $\left(\leq 10^{10}-10^{11}\right)$ of individual $\mathrm{Ig}$ species. This diver-

Address correspondence and reprint requests to William L. Carroll, M.D., Program in Human Molecular Biology and Genetics, University of Utah, Building 533, Room 3260, Salt Lake City, UT 84112.

Received for publication 31 August 1992 and in revised form 17 December 1992.

J. Clin. Invest.

(c) The American Society for Clinical Investigation, Inc.

$0021-9738 / 93 / 06 / 2734 / 10 \$ 2.00$

Volume 91, June 1993, 2734-2743 sity is generated by molecular mechanisms unique to lymphocytes, including the recombination of one of a number of $\mathrm{V}, \mathrm{J}$, and, in the case of IgVH genes, D germline elements, imprecise joining of these segments, and the combinatorial assortment of heavy and light chains (1-8). Further diversity may be generated by somatic mutation of rearranged genes ( 9 ). Although these processes may theoretically yield an almost unlimited number of individual antibody specificities, evidence from murine and human systems suggests that these events may not occur randomly (10-13). For example, in early life, the expression of certain $\mathrm{V}$ region segments and the utilization of other diversifiers is limited. This programmed utilization of specific $\mathrm{V}$ region genes may result in a changing immunoglobulin repertoire during development (14-16). Understanding the molecular mechanisms relevant to the generation of specific antibody in humans will provide important information on the generation of the antibody repertoire in normal health and development, in immunodeficiency states and in autoimmune disorders.

We have used the immune response to the bacterial pathogen Haemophilus influenzae type $\mathrm{b}(\mathrm{Hib})^{1}$ as a model to study the development of the human B cell immune repertoire (1720). Antibody directed against the capsular polysaccharide of Hib (Hib PS) confers immunity against this important bacterial pathogen. Naturally occuring antibody directed against this and other bacterial polysaccharides, however, develops relatively late (in the second year of life) $(21,22)$. Another notable feature of this immune response is its pauciclonality; most individuals produce only one to four antibody clonotypes, as detected by isoelectric focusing (23). We and others have shown that although a variety of IgVL genes may encode anti$\mathrm{Hib} \mathrm{PS} \mathrm{Ab}$, the IgVH response appears to be restricted to a small group of $\mathrm{VH}$ gene segments, in combination with a more diverse group of $\mathrm{D}$ and $\mathrm{JH}$ elements (17-19, 24, 25). To more clearly understand the nature of the restriction and the regulation of this antibody response in the outbred human population, we have produced additional heterohybridomas secreting human anti-Hib PS antibody ( $\mathrm{Ab}$ ) from immunized subjects. We confirm that most human anti-Hib PS Ab appears to be encoded by a small group of VH3 genes (perhaps three or four) and that additional restraint is evident in CDR-3 regions. Furthermore, both mutated and unmutated Ig genes participate in this immune response. VH segments of these antibodies are highly homologous to segments encoding autoantibodies and

1. Abbreviations used in this paper: Ab, antibody; Hib, Haemophilus influenzae type b; Hib PS, capsular polysaccharide of Hib. 
the Ab secreted by two of these hybridomas cross-react with self antigens.

\section{Methods}

Hybridoma cell lines. Heterohybridomas secreting human monoclonal anti-Hib PS Ab were obtained as previously described (17). Volunteers were immunized with either plain Hib PS vaccine (Praxis Biologicals, Rochester, NY), Hib PS diphtheria toxoid conjugate vaccine ( Hib PS-D; Connaught Laboratories, Swiftwater, PA), or Hib-oligosaccharide-CRM ${ }^{197}$ mutant Corynebacterium diphtheriae protein conjugate vaccine ( $\mathrm{Hb} \mathrm{OC}$; Lederle Laboratories, Wayne, $\mathrm{NJ}$ ). Peripheral blood lymphocytes were harvested $7 \mathrm{~d}$ after immunization and fused to the nonsecreting mouse myeloma cell line SP2/OAg14. Anti-Hib PS Ab was detected by binding to Hib PS in an ELISA (26) and by antibody binding to ${ }^{125} \mathrm{I}$-labeled antigen (27). Specificity was determined by inhibition of binding by $1.25 \mu \mathrm{g} / \mathrm{ml}$ of soluble Hib PS in this ELISA (26). The generation of hybridoma line $16 \mathrm{M} 3 \mathrm{C} 8$ has been described previously (28).

Cloning and sequencing of $\mathrm{VH}$ genes. Preparation of total RNA and subsequent cloning of rearranged IgVH genes amplified by PCR were performed as previously described (17). PCR products were isolated from low melting point agarose gel (FMC Bio Products, Rockland, $\mathrm{ME})$. Amplification products were either directly cloned into pCR 1000 phagemid vectors (Invitrogen, San Diego, CA ), or using artificial restriction enzyme sites incorporated in PCR products, directionally cloned into Bluescript II KS+ phagemid (Stratagene, La Jolla, CA) or M13 phage vectors (29).

Single or double-stranded sequencing of cloned inserts was done by the dideoxy technique (30). Two to seven independent clones were sequenced for all VH genes with the exception of SB1 /D8 and SD15, for which single clones were obtained.

The 16M3C8 VH gene was obtained by PCR amplification of total RNA reverse transcribed with antisense $C \gamma$ primer (5' GATGGGCCCTTGGTGGA $3^{\prime}$ ) and amplified with the sense VH primer $5^{\prime}$ ATAAGCTTCAGGTGCAGCTGCAGGAGTCTG $3^{\prime}$ and antisense JH primer 5' ATAGGATCCATGAGGAGACGGTGACCAGGGT 3'. The PCR product was cloned as described above.

Most closely homologous VH and D segments were identified by comparison of these sequences with those contained in the Genbank data base. The sequences of LSF2, RAY4, SB5/D6, SB1/D8, and ED8.4 have been previously reported (17).

Amplification of germline and rearranged $V H 3 b$ gene segments. To test whether nucleotide differences between the candidate VH3b germline genes LSG1.1 and LSG6.1 and rearranged VH3b segments occurred as a result of somatic mutation or if rearranged genes are encoded by as yet unidentified germline VH 3 b genes, a PCR-based assay was developed based on the method described by van Es et al. (31). Anti-Hib PS Ab VH segments from two unrelated subjects (LS and RC) contain novel base substitutions in FR3 compared to other rearranged genes and identified germline $\mathrm{VH} 3$ genes. To determine if these substitutions occur as a result of somatic mutation, PCR was used to amplify genomic DNA and rearranged anti-Hib PS Ab VH3b gene segments obtained from the two subjects. Two alternative antisense primers were used, corresponding to codons $75-81$ of the previously cloned germline VH3b gene LSG6.1 FR3 sequence (5' TTGCAGATACAGCGTGTTTTT $\left.3^{\prime}\right)^{2}$ or the same region of the rearranged LSF2 and RC3 VH segments (5' TTGCAGATACACCGTGCTCTG $3^{\prime}$ ). These antisense primers, therefore, differ at 4 of 21 nucleotide positions. For both genomic DNA and rearranged genes a sense primer corresponding to codons -4 to 3 of FR-1 (5' GTGTCCAGTGTGAGGTGCAGC $3^{\prime}$ ) was used. $200 \mathrm{ng}$ of genomic DNA or plasmid containing the rearranged VH3b segments LSF2 and RC3 was amplified in a 100- $\mu$ l reaction containing $70 \mathrm{pmol}$ of the FR-1 sense primer and 70 pmol of antisense "germline" FR-3 primer or "rearranged"

2. Adderson, E. E., F. Azmi, P. Wilson, P. Shackelford, and W. Carroll. The human VH3b gene subfamily is highly polymorphic. Manuscript submitted for publication.
FR-3 primer. Reaction mixtures contained $50 \mathrm{mM} \mathrm{KCl}, 10 \mathrm{mM}$ Tris $\mathrm{HCl} \mathrm{pH} 8.3,1.5 \mathrm{mM} \mathrm{MgCl}$, and $0.2 \mathrm{mM}$ deoxynucleotides. Cycles consisted of $1 \mathrm{~min}$ denaturation at $92^{\circ} \mathrm{C}, 1.5 \mathrm{~min}$ annealing at $65^{\circ} \mathrm{C}$ and 2 min extension at $72^{\circ}$ for 30 cycles.

PCR products were identified by ethidium bromide staining after electrophoresis in a $0.8 \%$ agarose gel, then transferred to a nylon membrane (Duralon UV; Stratagene, Inc.). Amplification products were hybridized with a 250-bp EcoR1 segment from clone ED8.4, which contains a VH3 segment and lacks the associated D and JH segments. Probe was labeled to high specificity using T7 DNA polymerase (32). Membrane was prehybridized and hybridized at $42^{\circ} \mathrm{C}$ in $2 \times$ Pipes buffer, $50 \%$ formamide, $1 \%$ SDS, and $150 \mu \mathrm{g} / \mathrm{ml}$ sheared and denatured salmon sperm DNA. After hybridization, the blot was washed with $2 \times$ SSC $/ 0.1 \%$ SDS for 15 min once at room temperature and with $0.2 \times \mathrm{SSC} / 0.1 \%$ SDS for $15 \mathrm{~min}$ twice at $60^{\circ} \mathrm{C}$ and exposed briefly to Hyperfilm-MP (Amersham Corp., Arlington Heights, IL).

Immunoassays. Binding of monoclonal Abs to Hib PS and self antigens was measured by ELISA. A panel of self antigens consisted of single-stranded DNA and double-stranded DNA (Calbiochem-Behring Corp., La Jolla, CA ), myosin, keratin, actin, tropomyosin, vimentin, laminin, elastin, and hyaluronic acid (Sigma Immunochemicals, St. Louis, MO), and aggregated IgG (supplied by Dr. A. Shikman, University of Oklahoma Health Sciences Center). Hib PS-poly-L-lysine, $10 \mu \mathrm{g} / \mathrm{ml}$ in PBS pH 7.4, or other test antigens, $10 \mu \mathrm{g} / \mathrm{ml}$ in carbonate-bicarbonate buffer, $\mathrm{pH} 9.6$, were coated directly on to microtiter plates (Immunlon 4; Dynatech, Chantilly, VA). Plates were blocked with dilution buffer ( $1 \%$ BSA, $0.05 \%$ Tween 20 in PBS) by incubation for $1 \mathrm{~h}$ at $37^{\circ} \mathrm{C}$. Between steps, plates were washed three times with $0.05 \%$ Tween $20 / 0.9 \mathrm{M} \mathrm{NaCl}$. Monoclonal anti-Hib PS Ab $(2-5 \mu \mathrm{g} / \mathrm{ml})$ was added and incubated at $4^{\circ}$ overnight. Bound $\mathrm{Ab}$ was detected with alkaline phosphatase-conjugated goat anti-human Ig (Sigma Immunochemicals). For competitive inhibition assays, antiHib PS Ab was preincubated overnight at $4^{\circ} \mathrm{C}$ with $10 \mu \mathrm{g} / \mathrm{ml}$ of soluble Hib PS or $100 \mu \mathrm{g} / \mathrm{ml}$ of dsDNA (Sigma Immunochemicals) or ssDNA (Sigma Immunochemicals) and assayed by ELISA as described above.

\section{Results}

Anti-Hib PS hybridoma cell lines. 15 anti-Hib PS secreting hybridomas obtained from 10 individuals were analyzed ( Table I). The heavy chain isotypic distribution of studied hybridomas was similar to the total group of hybridomas and to the serum immune response at $7 \mathrm{~d}$ after immunization $(39,40$, and Shackelford, P. G., manuscript in preparation). Eight hybridomas secreted kappa light chains and seven secreted lambda light chains.

IgVH nucleic acid sequences. Overall, the nucleic acid sequences of the $\mathrm{VH}$ segments used by the 15 hybridomas are 71.0-100.0\% homologous to one another (Fig. 1). We have previously found, under similar amplification conditions, an error rate for misincorporation of nucleotides by Taq polymerase of $<1 / 4,000 \mathrm{bp}$ sequenced (41). Thus, the majority of nucleotide differences between these anti-Hib PS IgVH segments are authentic. All hybridomas use members of the VH3 family (42), and 9 of 15 (SB5/D6, RAY4, CB20, JB32, JB21, RC3, LSF2, SB1 /D8 and ED6.1) are members of the smaller VH3b subfamily (Table II) (43). The VH3b-encoded IgVH genes are highly homologous to the previously described germline gene 9.1 (5) and to two germline genes, LSG6.1 and LSG12.1, obtained from subject $\mathrm{LS}^{2}$. SB5/D6, RAY4, CB20, JB32, JB21, RC3, and LSF2 are 93.5-98.9\% homologous to the LSG6.1 germline gene. SB1/D8 and ED6.1 are more closely homologous (93.2-93.8\%) to LSG12.1. ED8.4, SD15, Ann2, Ann6, CB6, and 16M3C8 VH sequences are 85.3$97.8 \%$ homologous to the germline gene VH26 (38). The similarities between the anti-Hib PS Ab VH segments and the candidate germline genes suggest that the $\mathrm{Ab} \mathrm{VH}$ segments may 


\begin{tabular}{|c|c|c|c|c|c|c|c|}
\hline \multirow[b]{2}{*}{ Hybridoma } & \multirow[b]{2}{*}{ Isotype } & \multirow[b]{2}{*}{ Age } & \multirow{2}{*}{$\begin{array}{l}\text { Vaccine } \\
\text { form }\end{array}$} & \multicolumn{2}{|c|}{ Total anti-Hib PS Ab } & \multirow[b]{2}{*}{ VH } & \multirow[b]{2}{*}{ VL } \\
\hline & & & & Before & After & & \\
\hline & \multicolumn{7}{|c|}{$\mu g / m l$} \\
\hline SB5/D6 & $\operatorname{Ig} A_{1} / \lambda$ & adult & PS-D & 3.0 & 688 & VH3 LSG6. $1^{2}$ & VAVII 4A (33) \\
\hline RAY4 & $\operatorname{IgA}_{2} / \lambda$ & adult & PS-D & 1.9 & 28 & VH3 LSG6.1 & VגVII 4A \\
\hline CB20 & $\operatorname{IgA}_{2} / \lambda$ & adult & $\mathrm{Hb} \mathrm{OC}$ & 21.0 & 75 & VH3 LSG6.1 & VXIII III.1 (34) \\
\hline JB32 & $\operatorname{IgA}_{1} / \lambda$ & $11 \mathrm{yr}$ & PS & 4.1 & 200 & VH3 LSG6.1 & VגVII 4A \\
\hline JB21 & $1 \mathrm{gG}_{2} / \lambda$ & $11 \mathrm{yr}$ & PS & 4.1 & 200 & VH3 LSG6.1 & V入II 2.1 (35) \\
\hline $\mathrm{RC} 3$ & $\operatorname{Ig} \mathrm{A} / \kappa$ & adult & PS-D & 1.1 & 300 & VH3 LSG6.1 & VkII A2 (36) \\
\hline LSF2 & $\operatorname{Ig} A_{1} / \lambda$ & adult & PS & $\mathrm{ND}^{\ddagger}$ & 138 & VH3 LSG6.1 & VגVII 4A \\
\hline SB1/D8 & $\mathrm{IgG}_{1} / \kappa$ & adult & PS-D & 3.0 & 688 & VH3 LSG12.1 ${ }^{2}$ & $\mathrm{NK}^{8}$ \\
\hline ED6.1 & $\mathrm{IgG}_{2} / \kappa$ & $4 \mathrm{yr}$ & PS-D & 0.8 & 22 & VH3 LSG12.1 & $\mathrm{V}_{K} 1$ clone $\mathrm{KC}-1$ (37) \\
\hline CB6 & $\operatorname{IgA} / \kappa$ & adult & $\mathrm{Hb} \mathrm{OC}$ & 21.0 & 75 & VH3 VH26 (38) & NK \\
\hline ED8.4 & $\operatorname{IgM} / \kappa$ & $4 \mathrm{yr}$ & PS-D & 0.8 & 22 & VH3 VH26 & NK \\
\hline SD15 & $\operatorname{IgA}_{2} / \kappa$ & $11 \mathrm{yr}$ & PS-D & 0.4 & 550 & VH3 VH26 & NK \\
\hline Ann2 & $\operatorname{Ig} A_{1} / \kappa$ & adult & $\mathrm{Hb} \mathrm{OC}$ & 1.7 & 110 & VH3 VH26 & VkII A2 \\
\hline Ann6 & $\operatorname{Ig} \mathrm{A} / \kappa$ & adult & $\mathrm{Hb} \mathrm{OC}$ & 1.7 & 110 & VH3 VH26 & NK \\
\hline $16 \mathrm{M} 3 \mathrm{C} 8$ & $\mathrm{IgG}_{2} / \lambda$ & adult" & PS & ND & ND & VH3 VH26 & VXII 2.1 \\
\hline
\end{tabular}

* Columns show name of hybridoma cell line, isotype of anti-Hib PS Ab secreted, age of subject at immunization, type of vaccine (PS, plain polysaccharide; PS-D, Hib PS conjugated to diphtheria toxoid; Hb OC, Hib oligosaccharide conjugated to CRM ${ }^{197}$ mutant diphtheria protein), concentration of total serum anti-Hib PS Ab immediately before and 1 mo postimmunization and most closely homologous germ-line $\mathrm{VH}$ and $\mathrm{V}_{\kappa} / \mathrm{V} \lambda$ segments identified.

${ }^{\ddagger}$ Not done.

$\$$ Not known.

" Pool of three adult donors.

derive from these genes or a small group of closely related germline elements.

The hybridomas JB21 and JB32 were obtained from the same subject and share identical VH segments and VDJ joinings. The complete homology of $\mathrm{VH}$ transcripts in these two hybridomas is unlikely to be a result of cross-contamination of PCR reactions, since each of these VH sequences was repeatedly isolated from these hybridomas and no additional heavy chain transcript was detected. In addition, different Ig heavy chain isotypes and different IgVL segments were used in the two hybridomas (JB21-IgG $/$ V $\lambda$ VII, JB32-IgA, / V $\lambda$ II ). Hybridization of HindIII-digested genomic DNA obtained from these cell lines with a human $\mathrm{JH}$ probe (44) demonstrated a 7.0-kb band in JB32 DNA (data not shown). No germline or rearranged $\mathrm{JH}$ band could be detected in DNA obtained from cell line JB21, reflecting the marked instability of these murinehuman heterohybridomas (45).

Four additional pairs of hybridomas were obtained from single subjects. The pairs SB5/D6 and SB1/D8, ED6.1 and ED8.4, and CB20 and CB6 use VH segments that are distinctly different and appear to derive from different germline genes. Ann2 and Ann6, obtained from the same subject use closely related IgVH genes and have identical VDJ joinings (see Table I).

Considerable heterogeneity exists in the CDR-3 region of anti-Hib PS IgVH genes. 10 different D segments are represented (Fig. 2). The length of these segments varies considerably from 1 to $34 \mathrm{bp}$. In general, these D segments are short and share little homology with known germline or rearranged D segments. The SB5/D6 D segment shares some segmental homology with DHQ52 and JB32/21 with D4C $(6,42,46)$. In $16 \mathrm{M} 3 \mathrm{C} 8$, "P" nucleotides may be present at the VH-D junction and in RAY4 at the D-J junction. Five different JH seg- ments are used (42). Although a variety of D and JH segments are used, certain D and JH combinations appear to be preferentially combined. Remarkably, in four instances, identical VDJ joints are shared by two or more hybridomas. ED8.4, CB6, and SD15, obtained from unrelated subjects, display identical VDJ joints with different VH segments, as do LSF2 and RC3. Ann2 and Ann6 share identical VDJ joints and use distinct but closely homologous VH gene segments and JB32 and JB21, from the same subject, share identical IgVH segments, as noted above.

Overall, amino acid translation of the nucleic acid sequences of these VH genes shows that $\sim 60 \%$ of differences in nucleic acid sequence from the putative germline genes result in amino acid replacements (Fig. 3 and Table II). When compared to candidate germline genes LSG6.1, LSG12.1, and VH26 sequences, the replacement/silent ratios of anti-Hib PS hybridoma genes are generally low, but exceed 3:1 in the CDR regions of ED6.1, SB1/D8, Ann2, and 16M3C8 and in FR regions of ED8.4. Although we cannot be confident that these rearranged genes are compared to the appropriate germline sequence, these replacement/silent ratios suggest that some of these VH segments may be mutated. Amino acid homology to candidate germline genes parallels that of nucleic acid homology in most instances. The amino acid homology in CDR regions of SD15 and $16 \mathrm{M} 3 \mathrm{C} 8$ to $\mathrm{VH} 26$; however, are 73 and $41 \%$, respectively, compared to nucleic acid homology of $85 \%$ and $64 \%$. Again, this may reflect selection as a result of somatic mutation or, alternatively, these genes may derive from other germline elements.

Analysis of somatic mutation of rearranged $V H 3 b$ genes. PCR products of the expected size of $245 \mathrm{bp}$ were observed only in reactions in which genomic DNA was amplified using the "germline" FR-3 primer, and in which the rearranged anti- 


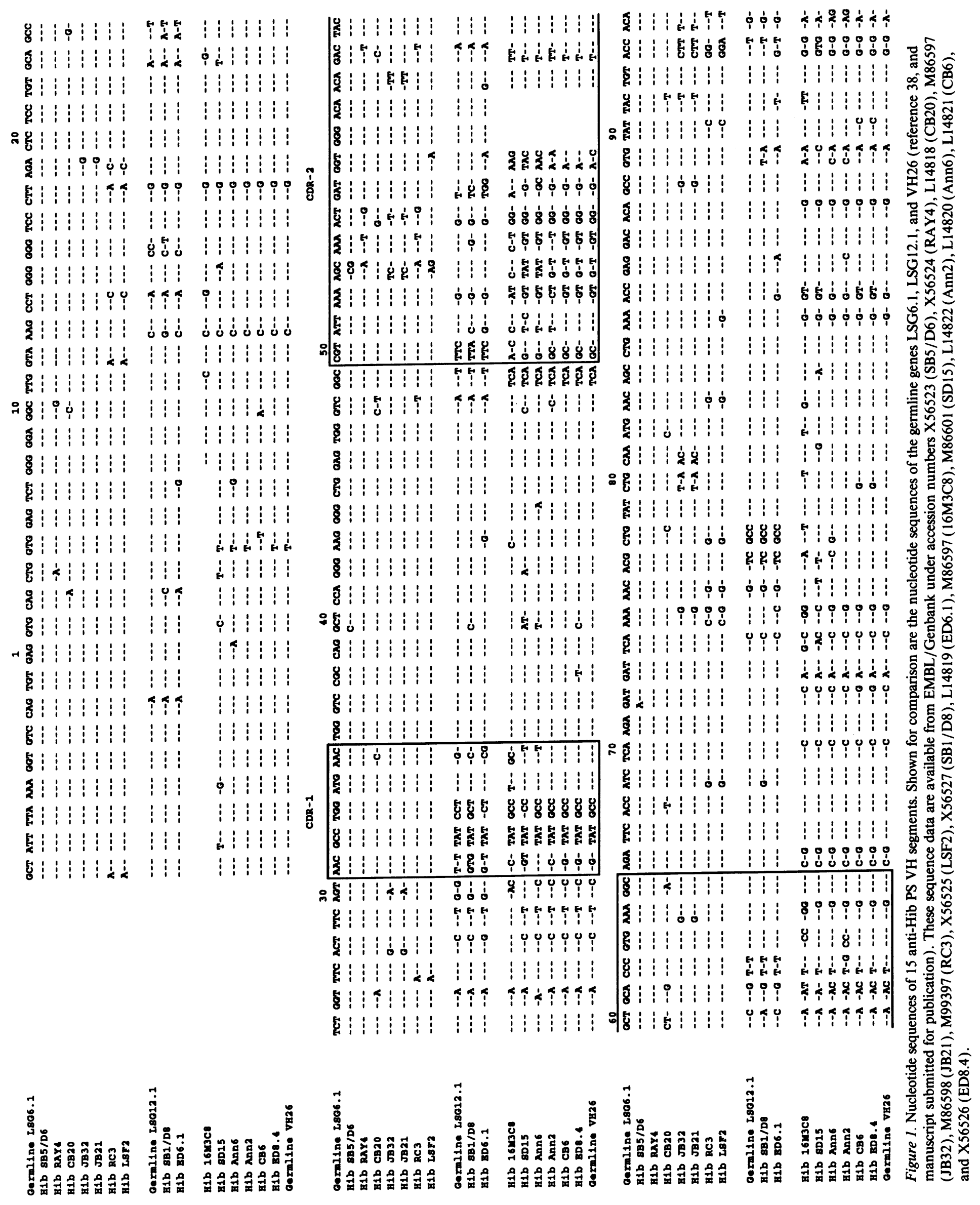




\begin{tabular}{|c|c|c|c|c|c|c|c|c|}
\hline & \multicolumn{5}{|c|}{ Nucleic acid homology } & \multicolumn{3}{|c|}{ Amino acid homology } \\
\hline & Overall (\%) & CDR (\%) & $(\mathrm{R} / \mathrm{S})$ & FR (\%) & $(\mathbf{R} / \mathrm{S})$ & Overall (\%) & $\operatorname{CDR}(\%)$ & FR (\%) \\
\hline \multicolumn{9}{|l|}{ Consensus LSG6.1 } \\
\hline Hib SB5/D6 & 98.8 & 97.2 & $(2: 0)$ & 99.2 & $(2: 0)$ & 97.2 & 95.8 & 97.6 \\
\hline Hib RAY498 & 98.1 & 94.4 & $(2: 2)$ & 99.2 & $(1: 1)$ & 97.2 & 91.7 & 99.0 \\
\hline Hib CB20 & 94.8 & 90.3 & $(6: 1)$ & 96.0 & $(5: 5)$ & 90.7 & 79.2 & 94.0 \\
\hline Hib JB32 & 93.8 & 91.6 & $(3: 3)$ & 94.4 & $(8: 6)$ & 91.7 & 87.5 & 92.9 \\
\hline Hib JB21 & 93.8 & 91.6 & $(3: 3)$ & 94.4 & $(8: 6)$ & 91.7 & 87.5 & 92.9 \\
\hline Hib RC3 & 93.5 & 94.4 & $(2: 2)$ & 92.9 & $(11: 7)$ & 88.9 & 91.7 & 88.1 \\
\hline Hib LSF2 & 93.5 & 95.8 & $(2: 1)$ & 92.9 & $(12: 6)$ & 88.9 & 95.8 & 86.9 \\
\hline \multicolumn{9}{|c|}{ Consensus LSG12.1 } \\
\hline Hib SB1/D8 & 93.8 & 86.1 & $(8: 2)$ & 96.0 & $(7: 3)$ & 87.0 & 70.8 & 91.7 \\
\hline Hib ED6.1 & 93.2 & 87.5 & $(7: 2)$ & 94.8 & $(7: 5)$ & 88.0 & 75.0 & 91.7 \\
\hline \multicolumn{9}{|l|}{ Consensus VH26 } \\
\hline Hib ED8.4 & 97.8 & 98.5 & $(0: 1)$ & 97.6 & $(5: 1)$ & 95.3 & 100.0 & 94.0 \\
\hline Hib CB6 & 97.8 & 98.5 & $(0: 1)$ & 97.6 & $(4: 2)$ & 95.3 & 100.0 & 94.0 \\
\hline Hib Ann2 & 95.9 & 86.4 & $(8: 1)$ & 98.4 & $(3: 1)$ & 90.6 & 68.2 & 96.4 \\
\hline Hib Ann6 & 94.3 & 87.9 & $(6: 2)$ & 96.0 & $(4: 6)$ & 91.5 & 77.3 & 95.2 \\
\hline Hib SD15 & 90.3 & 83.3 & $(8: 3)$ & 92.1 & $(14: 6)$ & 83.0 & 72.7 & 85.7 \\
\hline Hib $16 \mathrm{M} 3 \mathrm{C} 8$ & 85.3 & 65.7 & $(18: 4)$ & 91.5 & $(11: 7)$ & 73.3 & 40.9 & 83.8 \\
\hline
\end{tabular}

* Columns show names of anti-Hib PS antibody and germline genes these segments are compared to, overall percentage of nucleic acid homology, percent homology within CDR and framework regions and number of nucleic acid differences from the germline gene resulting in nucleic acid replacement $(\mathrm{R})$ or silent $(\mathrm{S})$ changes, and percentage amino acid homology of total VH segment, CDR, and framework regions.

Hib PS VH segments were amplified using the "rearranged" FR-3 primer (Fig. 4). Southern blot analysis using a probe specific for VH3 gene family members detected only those bands visible by ethidium bromide staining. The failure to amplify genomic DNA with the "rearranged" FR-3 antisense primer suggests the germline repertoire of the two subjects studied does not include a gene containing all of the nucleotide differences seen in FR-3 of the rearranged VH segments. At least a portion of these nucleotide differences from the candidate germline genes appear, therefore, to result from somatic mutation.

Immunoassays. Because of the high homology between IgVH segments encoding anti-Hib PS Ab and those encoding autoantibodies, six monoclonal anti-Hib PS Ab were tested for reactivity with a panel of autoantigens. Antibodies Ann2 and CB20 were reactive with both ssDNA and dsDNA (Fig. 5) and synthetic polynucleotides (dATP, dUTP, and dITP; data not shown). The reactivity of Ann2 and CB20 with DNA was low compared to pooled sera from patients with SLE. In a competitive inhibition assay, soluble Hib PS strongly inhibited DNA binding by these $\mathrm{Ab}$. However, binding to Hib PS could not be inhibited by $100 \mu \mathrm{g} / \mathrm{ml}$ of dsDNA, likely reflecting higher avidity for Hib PS. This is in agreement with the lower direct binding of these antibodies to DNA versus native Hib PS (Figs. 5, $A$ and $B$ ). In situ binding to DNA could not be demonstrated by indirect immunofluorescence staining of acetone-fixed rat heart cells (CRL-1446; American Type Culture Collection, Rockville, MD) $(47,48)$ or Crithidia, likely caused by the comparatively lower sensitivity of these assays, compared to the ELISA assay (data not shown).

There was no reactivity of our panel of anti-Hib PS Ab with other autoantigens (myosin, keratin, actin, tropomyosin, vimentin, laminin, elastin, or aggregated IgG).

\section{Discussion}

Our laboratory and others have studied the immune response to Hib PS as a model of the development of the human antibody repertoire. Our initial analysis of $\mathrm{VH}$ genes in five anti$\mathrm{Hib}$ PS Ab indicated that a small group of $\mathrm{VH} 3$ genes appeared to encode this immune response (17). However, in the outbred human population few definitive conclusions can be reached with such a small sample size. We, therefore, have isolated an additional $10 \mathrm{IgVH}$ genes, extending our analysis to 15 total IgVH sequences. The additional genes are also members of the VH3 gene family and appear to be related to three germline genes previously cloned in our laboratory ${ }^{2}$ or others (36). Seven of the anti-Hib PS Ab VH segments are highly homologous to the VH3b germline gene LSG6.1, two to the VH3b gene LSG12.1, and six to a VH3a germline gene, VH26 (38). The VH3b anti-Hib PS Ab VH segments are also closely homologous to the previously described germline gene 9.1 (5). Neither IgVH usage nor homology to putative germline genes appears to correlate with subject's age, vaccine formulation, heavy chain isotype, or IgVL usage.

All anti-Hib-PS heavy chains characterized by protein or nucleic acid sequence to date are encoded by members of the VH3 family, although a minority of subjects studied by serologic techniques also appear to express small amounts of antibody encoded by VH1 and VH4 gene family members $(17,24$, $49)$. It is estimated the human VH locus contains $50-300$ members (5). The VH3 family is relatively large (25-200 members ) and heterogeneous $(5,50,51)$. The exclusive usage of only a small number of related VH3 gene elements in the anti-Hib PS hybridomas reported here suggests that the heavy chains encoded by these genes are important for Hib PS binding. 


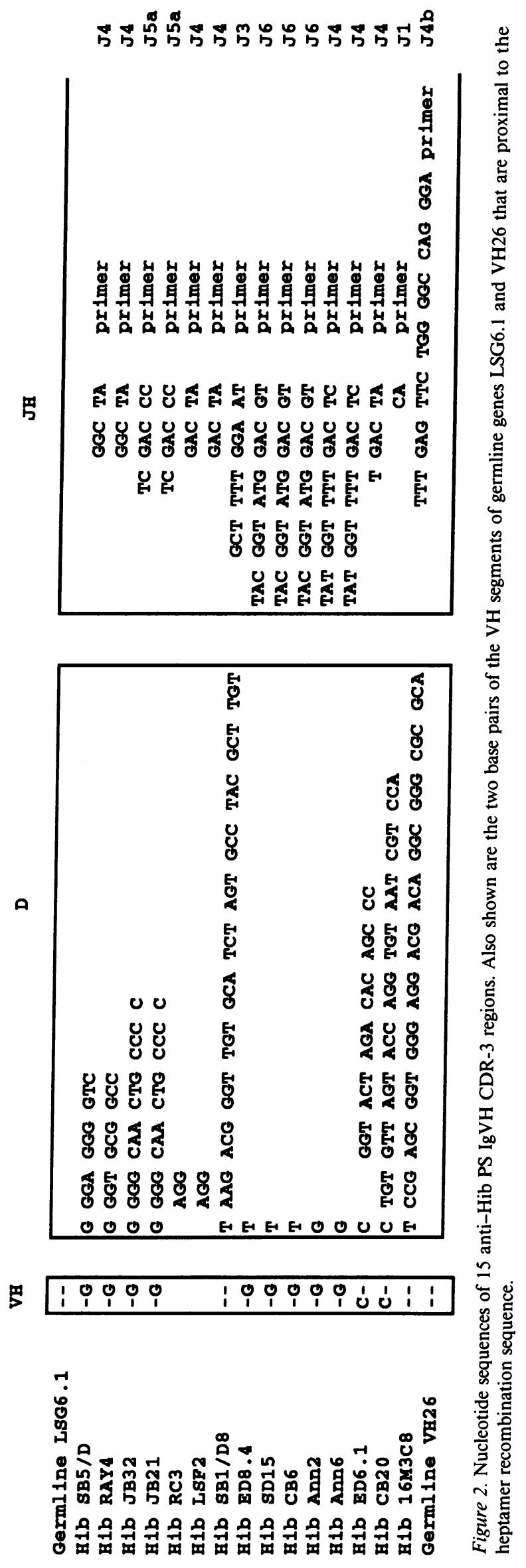

Two pairs of hybridomas were obtained from each of five subjects and analyses of these pairs are particularly interesting, since the antibody response to Hib originates from a few B cell clones (23). Three pairs of hybridomas (SB5/D6 and SB1/ D8, ED6.1 and ED8.4, as well as CB6 and CB20) use distinct VH genes and VDJ joints. Thus, each hybridoma originates from a distinct B cell clone. The hybridomas JB32 and JB21 share identical IgVH gene segments but differ in heavy chain isotype and light chain usage. Since the number of $\mathrm{VH}$ and D segments potentially available for combinatorial assortment is great, a "shared" VDJ segment would be expected to occur infrequently. This might occur, however, if a single pre-B cell were to give rise to distinct progeny with specific antigen binding potential. The use of shared VDJ segments and distinct IgVL rearrangements has previously been described in a hybridoma specific for antiinfluenza virus hemagglutinin $A b(52)$. The identification of two progeny from a single $B$ cell clone implies that clonal precursors capable of Hib PS binding may be relatively rare in the human immune repertoire. An alternative explanation is that IgVH usage and VDJ association may be so restricted that expression of identical IgVH genes in different anti-Hib PS B cell clones may be much more common than expected. Our unexpected finding of identical VDJ joints in IgVH genes obtained from unrelated subjects supports this hypothesis. We were unable to definitively determine which of these two possibilities is correct, since Southern blot analysis of $\mathrm{IgVH}$ genes of these hybridomas revealed a rearrangement in JB32 only. The lack of a detectable rearrangement in JB21 reflects the instability of these heterohybridomas. Both of these theories are consistent with the previous observation that individuals display only one to three clonotypes of anti-Hib PS Ab by isoelectric focusing and that these Ig patterns may be shared among individuals (23).

The hybridomas Ann2 and Ann6 share identical VDJ joinings and, although closely related, multiple replacement and silent base differences are noted in the VH segments. Both hybridomas secrete kappa light chains, and it is possible that these hybridomas, like JB21 and JB32, may be progeny of a single B cell. If encoded by a single germline gene, the differences in the Ann2 and Ann6 VH segments would likely be the result of somatic mutation. Using a PCR-based assay to detect base pair differences, we demonstrate that some anti-Hib PS IgVH segments (LSF2 and RC3) are mutated. However, somatic mutation appears to be limited in these anti-Hib PS genes and may occur in only a portion of the immune response. The presence of mutation does not appear to correlate with antigen formulation (subject LS received plain polysaccharide vaccine and subject RC, polysaccharide-protein conjugate vaccine). The absence of basepair differences in VH segments of clonal progeny JB2 1 and JB32 suggests that, in contrast to LSF2 and RC3, some anti-Hib PS IgVH genes are unmutated. Previous analysis of light chain variable region usage also demonstrated that a portion of these antibodies was encoded by unmutated versions of germline genes $(18,24,36)$. Both the paucity or absence of somatic mutation and the extreme restriction of antiHib PS VH usage may explain the poor response to Hib PS immunization and the increased incidence of invasive Hib disease in certain individuals and ethnic populations (53-55). That is, such individuals and groups may lack one or more important VH segments on the basis of genetic polymorphism and may be unable to be improve upon a less optimal germline gene by antigen-driven somatic mutation. 
Germl1ne ISG6.1

H1b SB5/D6

H1b RAY 4

H1b CB2O

H1b JB32

H1b JB21

H1b RC3

Hib LSF2

Germl1ne LSG12.1

HAb SB1/D8

H1b ED6.1

Hib $1643 \mathrm{CB}$

H1b SD15

Hib Ann6

H1b Ann2

H1b CB6

H1b ED8.4

cermline VH26

Cerml1ne LSG6.1

H1b SB5/D6

HIb RAY4

H1b CB2O

H1b JB32

H1b JB21

Hib RC3

HIb LSE2

Cerml1ne LsG12.1

H1b SB1/D8

H1b ED6. 1

H1b 16 MC

H1b SD15

H1b Ann6

H1b Ann2

Hib CB6

H1b ED8.4

cerml1ne VH26

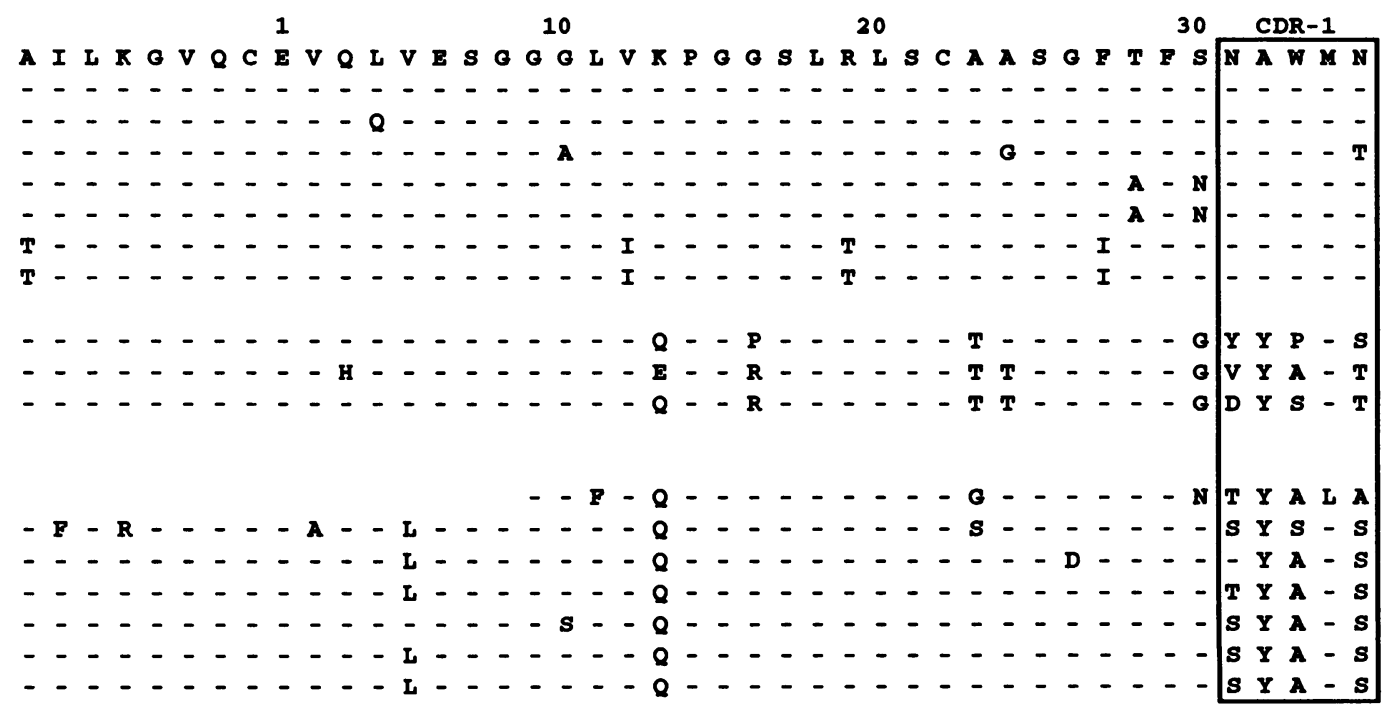

40

50

CDR-2

70

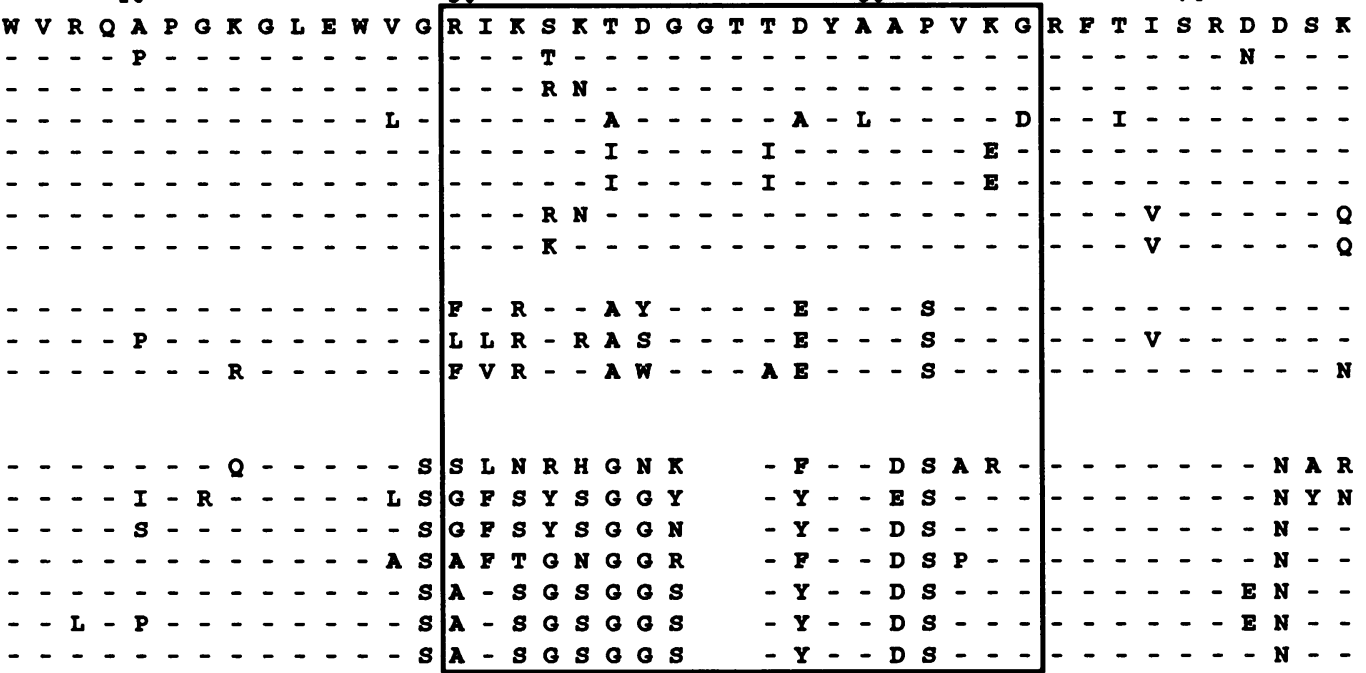

Germl1ne LSG6.1

H1b SB5/D6

H1b RAY 4

Hib CB2O

Hib JB32

H1b JB21

H1b RC3

HIB LSF2

Germline LsG12.1

H1b SB1/D8

H1b ED6.1

H1b $1643 \mathrm{CB}$

H1b SD15

H1b Ann6

H1b Ann2

HIb CB6

H1b ED8.4

Cerml1ne VH26
80

90

N T L Y L Q Y N S L K T E D T A V Y Y C T T

CDR-3

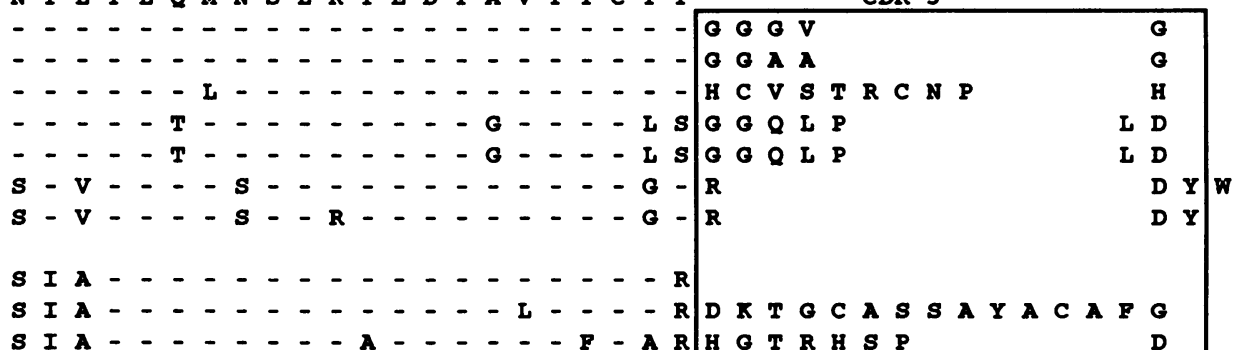

S I A - - - - A - - - F - A R G T R H S P

----- - D - - R V - - - I - F - A K P S G G R T T G G A F E F W Q G

$-\mathbf{M}-----N-\mathbf{R}------$ - V K $Q$

- V - - - - RA- - I I - - A R 0

$Y \in M D V$

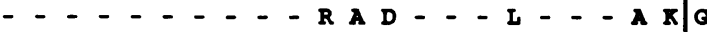

$---\mathbf{V}----\mathbf{R} \mathbf{V}--\ldots$

$---\mathbf{V}----\mathbf{R} \mathbf{V}------\mathbf{A} \mathbf{K} \boldsymbol{C}$

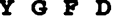

$Y \in E D$

$Y G M D$

Y G M D V $\mathbf{W}$

Figure 3. Translated amino acid sequences of 15 anti-Hib PS IgVH segments (see Figs. 1 and 3). Shown for comparison are the translated amino acid sequences of the germline genes LSG6.1, LSG12.1, and VH26. 


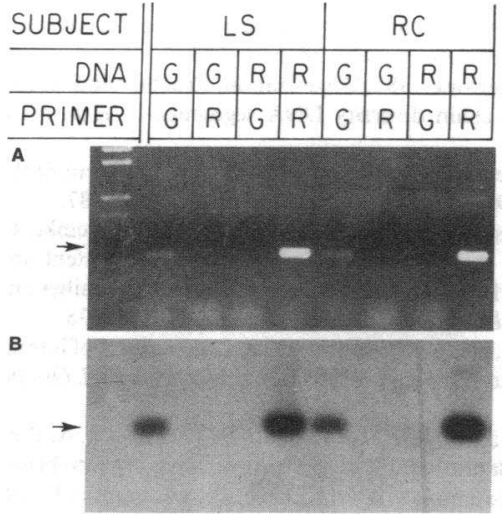

Figure 4. PCR analysis of somatic mutations in the rearranged antiHib PS IgVH genes LSF2 and RC3. Lanes show either genomic DNA $(G)$ obtained from subjects $L S$ and $\mathrm{RC}$, or plasmid containing the rearranged anti-Hib PS IgVH gene $(R)$ obtained from each subject amplified by primers corresponding to candidate germline genes $(G)$ or rearranged gene segments $(R) .(A)$ an ethidium bromide stained agarose gel showing amplified products. $(B)$ Southern blot of specific amplified products hybridized with a ${ }^{32} \mathrm{P}$-labelled $\mathrm{VH} 3$ probe. Arrows indicate amplification products of expected $245 \mathrm{bp}$.

A striking feature of the anti-Hib PS IgVH genes is the finding of shared VDJ joints among unrelated subjects. The disparity of length of $D$ segments implies that a variety of structural configurations of CDR-3 may permit antigen binding. However, about half of the D segments are extremely short (one to three bases) and the remainder of moderate length. It is conceivable, therefore, that CDR-3 length may identify Ab recognizing different epitopes ("groove" vs "cavity" type) (56). The shared VDJ rearrangements noted in this study may also occur as a result of selection at the DNA level. That is, junctional diversity might be limited in B cells responsive the Hib $\mathrm{PS}$. A prominent feature of the murine fetal $\mathrm{Ab}$ repertoire is the paucity of "N" addition (57), the use of relatively short D segments compared to adult animals and the use of a restricted number of $\mathrm{VH}$ and $\mathrm{JH}$ segments (58). Acquisition of $\mathrm{N}$ addition also procedes more slowly in the murine $\mathrm{Ly} 1^{+} \mathrm{B}$ cell subset, as compared to conventional B cells (59). Thus, the conserved pattern of VDJ rearrangement seen in anti-Hib PS $\mathrm{IgVH}$ genes might reflect rearrangement of precursors early in ontogeny or derivation from a discrete B cell subpopulation. Further characterization of both Hib PS epitopes and B cell subpopulations responding to Hib PS will be required to establish the molecular basis for restricted VDJ usage.

We show here that the anti-Hib PS Abs CB20 and Ann2 bind dsDNA, ssDNA and polynucleotides. It has been hypothesized that the basis for cross-reactive immune recognition of bacterial polysaccharides and DNA is the structurally similar repetitive phosphodiester linkage common to both macromolecules (56). Analysis of IgVH segments of these anti-Hib PS Ab suggests a molecular basis for anti-DNA cross-reactivity, al- though the precise features distinguishing polyreactive from monospecific $\mathrm{Ab}$ are not obvious. The $\mathrm{VH}$ segments described here are highly homologous to gene segments encoding autoantibodies. An anti-Sm Ab has a nucleic acid sequence identical to the 9.1 germline sequence and rheumatoid factor and antiDNA Abs $\left(16 / 6 \mathrm{Id}^{+}\right)$are encoded by gene segments identical to VH26 $(38,42)$, germline genes closely homologous to CB20 and Ann2, respectively. However, several nonautoreactive anti-Hib PS VH genes are more homologous to the 9.1 and VH26 genes than CB20 and Ann2. Although CDR-3 has been implicated in determining autoreactive potential (60), CB20 and Ann2 VDJ joints are similar or identical to non-cross-reactive anti-Hib PS clones. The presence of Arg in CDR-3, common in murine anti-DNA Ab (61) is inconsistent in these antiHib PS Ab, although nearly invarient in IgVL segments ( 18 , $19,25,36)$. Analysis of anti-DNA antibodies from MRL/lpr mice indicates that the heavy chain provides essential determinants for antigen binding but that the various associated light chains modulate binding activity (62). The CB20 IgVL gene is encoded by a V $\lambda$ III gene family member that appears to be infrequently expressed in this immune response and the Ann2 $V_{\kappa}$ segment differs from other described $V_{\kappa}$ II A2-encoded anti-Hib PS Ab in that its nucleic acid sequence differs at a number of positions from that of the germline A2 gene (19). Thus, it is possible that combinatorial assortment or light chain usage may play a role in mediating fine specificity of these antibodies. Finally, antigen-driven somatic mutation has been shown to result in the acquisition of cross-reactivity and selfreactivity $(63,64)$. The anti-Hib PS Ab described in this study appear to be mutated but no single amino acid replacement distinguishes cross-reactive from monospecific antibody. Further characterization of bacterial and self epitopes, $x$-ray crystallographic studies of antibody-antigen complexes and the construction of chimeric antibodies combining portions of antiHib PS and autoantibodies may clarify which of the subtle differences in these antibodies is responsible for fine specificity.

Considerable data associates the immune response to bacterial polysaccharides with the generation of anti-DNA $\mathrm{Ab}$. The autoimmune disease of NZB / W mice is diminished in a germfree environment (65) and mice homozygous for the xid mutation demonstrate a marked reduction in both anti-DNA and in antipolysaccharide $\mathrm{Ab}(66)$. In humans, autoreactive antibodies are elicited by infection or by LPS-stimulation of normal B cells (67) and in response to infection and thus may be a feature of many normal immune responses. For example, the immune response against both Streptococcus pneumoniae and Klebsiella species is marked by the expression of anti-DNA associated idiotypes $(68,69)$. Hib is a ubiquitous pathogen, and most individuals have acquired protective levels of antiHib PS Ab by 5 yr of age (22). The vast majority of individuals exposed to Hib PS do not develop autoimmune disease, sug-
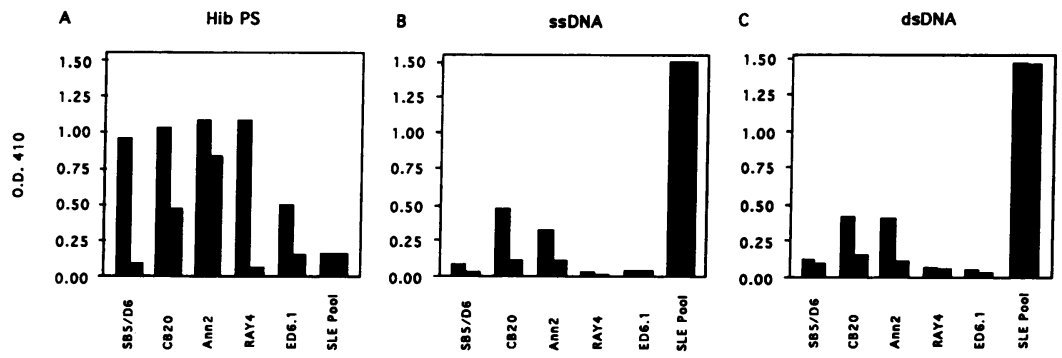

Figure 5. Fine antigen specificity of five monoclonal anti-Hib PS Ab. Graphs show reactivity of anti-Hib PS Ab to $(A)$ Hib PS, $(B)$ single-stranded DNA, and $(C)$ double-stranded DNA in the presence (stippled bars) or absence (solid bars) of preincubation with $10 \mu \mathrm{g} / \mathrm{ml}$ of soluble Hib PS. Also shown is the reactivity of pooled sera from patients with SLE. 
gesting that proliferation and expression of anti-Hib PS Ab reactive with self antigens may be limited. That is, by the process of generating hybridomas, we may have captured a B cell that, although present at $7 \mathrm{~d}$ after immunization, is not expanded and may not contribute to the normal serum anti-Hib PS Ab repertoire. However, under certain conditions the antigen-driven expansion of autoantibody-producing B cells may be stimulated or perpetuated by exposure to microorganisms. It has been hypothesized that disordered regulation of variable gene usage by B cells, such as might result from the deletion of pivotal genes in the anti-Hib PS repertoire, may lead to aberrant expression of autoreactive clones in response to Hib PS or other external antigens. Olee and co-workers have shown that, in humans, deletion of the Humhv 3005 VH segment is noted significantly more frequently in patients with systemic lupus erythematosus and rheumatoid arthritis than in normal controls (70). An alternative explanation for the infrequent occurrence of autoimmune disease in individuals exposed to bacterial polysaccharides is that "polyreactive" antibodies with low affinity for DNA may differ from pathologic autoantibodies. The affinity of CB20 and Ann2 for DNA appears to be significantly lower than that for Hib PS. "Naturally occurring" autoantibodies, in general, are of the IgM isotype, are polyreactive and relatively low affinity, whereas autoantibodies implicated in the pathogenesis of autoimmune disorders are often IgG, high affinity, and monospecific (71). Finally, somatic mutation might result in the acquisition of low affinity polyreactivity or pathologic autoreactivity, but occur at a very low rate $(64)$.

We have demonstrated that the IgVH sequences of human anti-Hib PS Ab appear to be encoded by a limited number of VH3 germline elements closely homologous to sequences expressed preferentially in the early fetal repertoire. These $\mathrm{VH}$ genes are very similar to those encoding autoantibodies, and two of these Abs cross-react with DNA, suggesting that a role may exist for $\mathrm{Ab}$ encoded by these genes in both the maturation of the normal immune repertoire and in the pathogenesis of autoimmune disease. Genetic polymorphisms involving critical IgVH segments may explain the increased susceptibility of individuals and populations to invasive Hib infection. Similarly, such polymorphisms may be associated with the induction or exacerbation of autoimmune disorders. Ongoing studies of the expression and structure of these important gene segments will provide insight into these issues.

\section{Acknowledgments}

The authors thank Drs. Harvey R. Colten, Michael A. Simmons, and Dan M. Granoff for their support, and Drs. J. Martin Johnston and Stephen M. Prescott for their critical review of the manuscript.

This work was supported by the Lattner Foundation, the Allison Hope Hellenbeck Fund, Grant 61 from the March of Dimes, the Markey Center in Molecular Biology of Human Diseases at Washington University, Grants R01-A119350 and AI-17217 from the National Institutes of Health, a Basil O'Connor Starter Scholar Research Award (W. L. Carroll), the Medical Research Council of Canada and a Pediatric Fellowship Award from Connaught Laboratories, Inc. (E. E. Adderson).

\section{References}

1. Tonegawa, S. 1983. Somatic generation of antibody diversity. Science (Wash. DC). 302:575-581.
2. Sakano, H., R. Maki, Y. Kurosawa, W. Roeder, and S. Tonegawa. 1980. Two types of somatic recombination are necessary for the generation of complete immunoglobulin heavy chains. Nature (Lond.). 286:676-683.

3. Kurosawa, Y., and S. Tonegawa. 1982. Organization, structure and assembly of immunoglobulin heavy chain diversity DNA segments. J. Exp. Med. 155:201-218.

4. Alt, F. W., T. K. Blackwell, and G. D. Yancopoulos. Development of the primary antibody repertoire. 1987. Science (Wash. DC). 238:1079-1087.

5. Berman, J. E., S. J. Mellis, R. Pollock, C. L. Smith, H. Suh, B. Heinke, C. Kowal, U. Surti, L. Chess, C. R. Cantor, and F. W. Alt. 1988. Content and organization of the human IgVH loci-definition of three new VH families and linkage to the IgCH locus. EMBO (Eur. Mol. Biol. Organ.) J. 7:727-738.

6. Ichihara, I., H. Matsuoka, and Y. Kurosawa. 1988. Organization of human immunoglobulin heavy chain diversity gene loci. EMBO (Eur. Mol. Biol. Organ.) J. 7:4141-4150.

7. Desiderio, S. V., G. D. Yancoupolos, M. Paskind, E. Thomas, M. A. Boss, N. Landau, F. W. Alt, and D. Baltimore. 1984. Insertion of N regions into heavychain genes is correlated with expression of terminal deoxytransferase in B cells. Nature (Lond.). 311:752-755.

8. Lewis, S., A. Gifford, and D. Baltimore. 1985. DNA elements are asymmetrically joined during the site specific recombination of kappa Ig genes. Science (Wash. DC). 228:677-685.

9. French, D. L., R. Laskov, and M. D. Scharff. 1989. The role of somatic hypermutation in the generation of antibody diversity. Science (Wash. DC) 244:1152-1157.

10. Yancoupolos, G. D., S. V. Desiderio, M. Paskind, J. F. Kearney, D. Baltimore, and F. W. Alt. 1984. Preferential utilization of the most JH-proximal VH gene segments in pre-B cell lines. Nature (Lond.). 311:727-733.

11. Alt, F. W., G. D. Yancoupolos, T. K. Blackwell, L. Wood, E. Thomas, M. Boss, R. Coffman, N. Rosenberg, S. Tonegawa, and D. Baltimore. 1984. Ordered rearrangement of immunoglobulin heavy chain variable region segments. $E M B O$ (Eur. Mol. Biol. Organ.) J. 3:1209-1219.

12. Perlmutter, R. M., J. F. Kearney, S. P. Chang, and L. E. Hood. 1985 Developmentally controlled expression of immunoglobulin VH genes. Science (Wash. DC). 227:1597-1601

13. Malynn, B. A., G. D., Yancopoulos, J. E. Barth, C. A. Bona, F. W. Alt 1990. Biased expression of JH-proximal VH genes occurs in the newly generated repertoire of neonatal and adult mice. J. Exp. Med. 171:843-859.

14. Klinman, D. M., Y. Ishigatsubo, and A. D. Steinberg. 1988. Acquisition and maturation of expressed $B$ cell repertoires in normal and autoimmune mice. J. Immunol. 141:801-806.

15. Riley, S. C., B. G. Froscher, P.-J. Linton, D. Zharhary, K. Marcu, and N. R. Klinman. 1989. Altered VH gene segment usage in the response to phosphorylcholine by aged mice. J. Immunol. 143:3798-3805.

16. Nicoletti, C., C. Borghesi-Nicoletti, X. Yang, D. H. Shultze, and J. Cerny. 1991. Repertoire diversity of antibody response to bacterial antigens in aged mice. II. Phosphorylcholine-antibody in young and aged mice differ in both VH/ VL gene repertoire and in specificity. J. Immunol. 147:2750-2755.

17. Adderson, E. E., P. G. Shackelford, A. Quinn, and W. L. Carroll. 1991. Restricted Ig heavy chain $\mathrm{V}$ gene usage in the human antibody response to Hae mophilus influenzae type b capsular polysaccharide. J. Immunol. 147:16671674.

18. Adderson, E. E., P. G., Shackelford, R. A. Insel, A. Quinn, P. M. Wilson, and W. L. Carroll. 1992. Immunoglobulin light chain variable region gene sequences for human antibodies to Haemophilus influenzae type b capsular polysaccharide are dominated by a limited number of $V_{\kappa}$ and $V \lambda$ segment and $V J$ combinations. J. Clin. Invest. 89:729-738.

19. Adderson, E. E., P. G. Shackelford, A. Quinn, P. M. Wilson, and W. L. Carroll. 1993. Diversity of immunoglobulin light chain usage in the human immune response to Haemophilus influenzae type b capsular polysaccharide. Pediatr. Res. 33:307-311.

20. Insel, R. A., E. E. Adderson, and W.rL. Carroll. 1992. The repertoire of human antibody to the Haemophilus influenzae type b capsular polysaccharide. Int. Rev. Immunol. 9:25-43.

21. Robbins, J. B., J. C. Parks, R. Schneerson, and J. K. Whishart. 1973. Quantitative measurement of 'natural' and immunization induced Haemophilus influenzae type b capsular antibodies. Pediatr. Res. 7:103-110.

22. Peltola, H., H. Kayhty, M. Virtanen, and P. H. Makela. 1984. Prevention of Haemophilus influenzae type b bacterial infections with the capsular polysaccharide vaccine. $N$. Engl. J. Med. 310:1561-1565.

23. Insel, R. A., A. Kittelberger, and P. Anderson. 1985. Isoelectric focusing of human antibody to the Haemophilus influenzae b capsular polysaccharides: restricted and identical spectrotypes in adults. J. Immunol. 135:2810-2816.

24. Scott, M. G., J. J. Tarrand, D. L. Crimmins, D. W. McCourt, N. R. Seigel, C. E. Smith, and M. H. Nahm. 1989. Clonal characterization of the human IgG antibody repertoire to Haemophilus influenzae type b polysaccharide II. IgG antibodies contain $\mathrm{VH}$ genes from a single $\mathrm{VH}$ family and $\mathrm{VL}$ genes from at least four VL families. J. Immunol. 143:293-298.

25. Scott, M. G., D. L. Crimmins, D. W. McCourt, G. Chung, K. F. Schable, R. Thiebs, E.-M. Quenzel, H. G. Zachau. 1991. Clonal characterization of the 
human IgG antibody repertoire to Haemophilus influenzae type b polysaccharide. IV. The less frequently expressed VL are heterogenous. J. Immunol. 147:4007-4013

26. Shackelford, P. G., D. M. Granoff, S. J. Nelson, M. G. Scott, D. S. Smith and M. H. Nahm. 1987. Subclass distribution of human antibodies to Haemophilus influenzae type b capsular polysaccharide. J. Immunol. 138:587-592.

27. Granoff, D. M., P. G. Shackelford, J. P. Pandey, and E. G. Boies. 1986 Antibody responses to Haemophilus influenzae type b polysaccharide vaccine in relation to the $\mathrm{Km}(1)$ and $\mathrm{G} 2 \mathrm{~m}(23)$ immunoglobulin allotypes. J. Infect. Dis. 154:257-264.

28. Gigliotti, F., L. Smith, and R. A. Insel. 1984. Reproducible production of protective monoclonal antibodies by fusion of peripheral blood lymphocytes with a mouse monoclonal cell line. J. Infect. Dis. 149:43-47.

29. Messing, J., B. Gronenburn, B. Muller-Hill, and P. H. Hofschneider 1977. Filimentous coliphage M13 as a cloning vehicle: insertion of a Hind II fragment of the lac regulatory region in M13 replicative form in vitro. Proc. Natl. Acad. Sci. USA. 74:3642-3646.

30. Sanger, F., S. Nicklen, and A. R. Coulson. 1977. DNA sequencing with chain terminating inhibitors. Proc. Natl. Acad. Sci. USA. 79:5463-5467.

31. van Es, J. H., F. G. J. Gmelig Meyling, W. R. M. van de Akker, H. Aanstoot, R. H. M. Derksen, and T. Logtenberg. 1991. Somatic mutation in the variable regions of a human IgG anti-double-stranded DNA autoantibody suggest a role for antigen in the induction of systemic lupus erythematosus. J. Exp. Med. 173:461-470.

32. Feinberg, A. P., and B. Vogelstein. 1983. Technique for radiolabelling DNA restriction endonuclease fragments to high specific activity. Anal. Biochem. 132, 6-13.

33. Anderson, M. L. M., M. F. Szajnert, J. C. Kaplan, L. McColl, and B. D. Young. 1984. The isolation of a human $\mathrm{Ig} V \lambda$ gene from a recombinant library of chromosome 22 and estimation of the copy number. Nucleic Acids Res. 12:66476660 .

34. Combriato, G., and H.-G. Klobeck. 1991. V $\lambda$ and $J \lambda-C \lambda$ gene segments of the human immunoglobulin locus are separated by $14 \mathrm{~kb}$ and rearrange by a deletion mechanism. Eur. J. Immunol. 21:1513-1522.

35. Brockly, F., D. Alexandre, P. Chuchana, S. Huck, G. Lefranc, and M.-P. Lefranc. 1989. First nucleotide sequence of a human immunoglobulin variable gene belonging to subgroup II. Nucleic Acids Res. 17:3976.

36. Scott, M. G., D. L. Crimmins, D. W. McCourt, I. Zocher, R. Theibe, H. G. Zachau, and M. H. Nahm. 1989. Clonal characterization of the human IgG antibody response to Haemophilus influenzae type b polysaccharide. III. A single $V_{K} I I$ gene and one of several $J_{K}$ genes are joined by an invariant arginine to form the most common L chain $\mathrm{V}$ region. J. Immunol. 143:4110-4116.

37. Kato, S., K. Tachibana, N. Takayama, H. Kataoka, M. Yoshida, and T. Takano. 1991. Genetic recombination in chromosomal translocation $\mathrm{t}(2: 8)$ (p11:q24) of a Burkitt's lymphoma cell line, KOBK101. Gene (Amst.) 97:239-244.

38. Chen, P. P., M. Liu, S. Sinha, and D. A. Carson. 1988. A 16/6 idiotype positive anti-DNA antibody is encoded by a conserved $\mathrm{VH}$ gene with no somatic mutation. Arthritis Rheum. 31:1429-1431.

39. Tarkowski, A., C. Lue, Z. Molodoveanu, H. Kiyona, J. R. McGhee, and J. Mestecky. 1990. Immunization of humans with polysaccharide vaccines induces systemic predominantly polymeric IgA2 subclass antibody responses. J. Immunol. 144:3770-3800.

40. Ambrosino, D. M., W. Greif, C. Thompson, and G. R. Siber. 1990. k and 1 light chain composition of antibody to the capsular polysaccharide of Haemophilus influenzae type b. J. Inf. Dis. 161:922-925.

41. Johnston, J. M., M. T. Yu, and W. L. Carroll. 1991. C-myc hypermutation is ongoing in endemic, but not all Burkitt's lymphoma. Blood. 78:2419-2425.

42. Kabat, E. A., T. T. Wu, M. Reid-Miller, H. M. Perry, and K. S. Gottesman. 1987. Sequence of Proteins of Immunological Interest. US Public Health Service, Bethesda, MD.

43. Sanz, I., H. Dang, M. Takei, N. Talal, and J. D. Capra. 1989. VH sequence of a human anti-SM autoantibody. J. Immunol. 142:883-886.

44. Ravetch, J. V., U. Siebenlist, S. Korsmeyer, T. Waldmann, and P. Leder. 1981. Structure of the human immunoglobulin $\mu$ locus: characterization of embryonic and rearranged $\mathrm{J}$ and $\mathrm{D}$ genes. Cell. 27:583-591.

45. Carroll, W. L., K. Thielemans, J. Dilley, and R. Levy. 1986. Mouse $\times$ human heterohybridomas as fusion partners with human B cell tumors. J. Immunol. Methods. 89:61-72.

46. Sanz, I. 1991. Multiple mechanisms participate in the generation of diversity of human H chain CDR3 regions. J. Immunol. 147:1720-1729.

47. Cunningham, M. W. and R. A. Swerlick. 1986. Polyspecificity of antiStreptococcal murine monoclonal antibodies and their implications in autoimmunity. J. Exp. Med. 164:998-1012.

48. Cunningham, M. W. 1992. Group A Streptococci: Molecular mimicry, autoimmunity, and infection. In Microbial Adhesion and Invasion. M. Hook and L. Swiralski, editors. Springer-Verlag New York Inc, NY. 149-169.
49. Silverman G. J., and A. H. Lucas. 1991. Variable region diversity in human circulating antibodies specific for the capsular polysaccharide of Haemophilus influenzae type b. J. Clin. Invest. 88:911-920.

50. Willems van Dijk, K., H. W. Schroeder, Jr., R. M. Perlmutter, and E. C. B. Milner. 1989. Heterogeneity in the human immunoglobulin VH locus. J. Immunol. 142:2547-2545.

51. Sasso, E. H., K. Willems van Dijk, and E. C. B. Milner. 1990. Prevalence and polymorphism of human VH3 genes. J. Immunol. 145:2751-2757.

52. Caton, A. J. 1990. A single pre-B cell can give rise to antigen-specific B cells that utilize distinct immunoglobulin gene rearrangements. J. Exp. Med. 172:815-825.

53. Granoff, D. M., K. E. Sheetz, M. H. Nahm, J. V. Madassery, and P. G. Shackelford. 1988. Further immunologic evaluation of children who develop Haemophilus disease despite previous vaccination with type $\mathrm{b}$ polysaccharide vaccine. Monogr. Allergy. 23:256-268.

54. Ward, J. J., H. S. Margolis, M. K. Lum, D. W. Fraser, and T. R. Bender. 1981. Haemophilus influenzae disease in Alaskan eskimos: characteristics of a population with an unusual incidence of invasive disease. Lancet $i$ : 1281-1285.

55. Coulehan, J. L., R. H. Michaels, C. Hallowell, R. Schults, T. K. Welty, and J. S. C. Kuo. 1984. Epidemiology of Haemophilus influenzae type b disease among Navajo indians. Pub. Hlth. Rep. 99:404-409.

56. Kabat, E. A., K. G. Nickerson, J. Liao, L. Grossbard, E. F. Osserman, E Glickman, L. Chess, J. B. Robbins, R. Schnerson, and Y. Yang. 1986. A human monoclonal macroglobulin with specificity for $\mathrm{a}(2 \rightarrow 8)$-linked poly- $N$-acetyl neuraminic acid, the capsular polysaccharide of group B meningococci and $E s c h e-$ richia coli $\mathrm{K} 1$ which crossreacts with polynucleotides and with denatured DNA. J. Exp. Med. 164:642-654.

57. Feeney, A. J. 1990. Lack of $\mathrm{N}$ regions in fetal and neonatal mouse immunoglobulin V-D-J junctional sequences. J. Exp. Med. 172:1377-1390.

58. Bangs, L. A., I. E. Sanz, and J. M. Teale. 1991. Comparison of D, JH, and junctional diversity in the fetal, adult, and aged B cell repertoires. J. Immunol. 146:1996-2004.

59. Gu, H., I. Forster, and K. Rajewsky. 1990. Sequence homologies, N sequence insertion and $\mathrm{JH}$ gene utilization in $\mathrm{V}_{\mathbf{H}} \mathrm{DJ}_{\mathrm{H}}$ joining: implications for the joining mechanism and the ontogenetic timing of Ly1 B cell and B-CLL progenitor generation. EMBO (Eur. Mol. Biol. Organ.) J. 9:2133-2140.

60. Newkirk, M. M., H. Gram, G. F. Heinrich, L. Ostberg, J. D. Capra and R. L. Wasserman. 1988. Complete protein sequences of the variable regions of the cloned heavy and light chains of a human anti-cytomegalovirus antibody reveal a striking similarity to human monoclonal rheumatoid factors of the Wa idiotypic family. J. Clin. Invest. 81:1511-1518.

61. Shlomchik, M., M. Mascelli, H. Shan, M. Z. Radic, D. Pietsky, A. Marshak-Rothstein, and M. Weigert. 1990. Anti-DNA antibodies from autoimmune mice arise by clonal expansion and somatic mutation. J. Exp. Med. 171:265297.

62. Schlomchik, M. J., A. H. Aucoin, D. S. Pisetsky, and M. G. Weigert. 1987. Structure and function of anti-DNA autoantibodies derived from a single autoimmune mouse. Proc. Natl. Acad. Sci. USA. 84:1950-1954.

63. Schlomchik, M. J., A. Manshak-Rothstein, C. B. Wolfowicz, T. L. Rotgstein, and M. G. Weigert. 1987. The role of clonal selection and somatic mutation in autoimmunity. Nature (Lond.). 328:805-811.

64. Diamond, B. and M. D. Scharff. 1984. Somatic mutation of the T15 heavy chain gives rise to an antibody with autoantibody specificity. Proc. Natl. Acad. Sci. USA. 81:5841-5844.

65. Unni, K. K., K. E. Holley, F. C. McDuffie, and J. L. Titus. 1975. Comparative study of NZB mice under germ-free and conventional conditions. J. Rheumatol. 2:36-44.

66. Steinberg, B. J., P. A. Smathers, K. Fredericksen, and A. D. Steinberg. 1982. Ability of the xid gene to prevent autoimmunity in (NZB $\times$ NZB $)$ F1 mice during the course of their natural history, after polyclonal stimulation or following immunization with DNA. J. Clin. Invest. 70:587-597.

67. Fournie, G. J., P. H. Lambert, and P. A. Miescher. 1974. Release of DNA in circulating blood and induction of anti-DNA antibodies after injection of bacterial lipopolysaccharides. J. Exp. Med. 140:1189-1206.

68. Grayzel, A., A. Solomon, C. Aranow and B. Diamond. 1991. Antibodies elicited by pneumococcal antigens bear an anti-DNA-associated idiotype. $J$. Clin. Invest. 87:842-846.

69. El-Roiey, A., O. Sela, D. A. Isenberg, R. Feldman, B. C. Colaco, R. C. Kennedy, and Y. Schoenfeld. 1987. The sera of patients with Klebsiella infection contain a common anti-DNA idiotype (16/6 Id) and anti-polynucleotide activity. Clin. Exp. Immunol. 67:507-515.

70. Olee, T., P. M. Yang, K. A. Siminovitch, N. J. Olsen, J. Hillson, J. Wu, F. Kozin, D. A. Carson, and P. P. Chen. 1991. Molecular basis of an autoantibodyassociated restriction fragment length polymorphism that confers susceptibility to autoimmune diseases. J. Clin. Invest. 88:193-203.

71. Pascual, V., and J. D. Capra. 1991. Human immunoglobulin heavy-chain variable region genes: organization, polymorphisms and expression. $A d v$. Im munol. 49:1-70. 